Annals of Warsaw University of Life Sciences - SGGW

Land Reclamation No 46 (2), 2014: 115-123

(Ann. Warsaw Univ. of Life Sci. - SGGW, Land Reclam. 46 (2), 2014)

\title{
Usability of fly ash for filtration barriers
}

\author{
ANDRZEJ GRUCHOT ${ }^{1}$, ANNA MADEJ $^{2}, \mathrm{KAROLINA} \mathrm{KOŚ}^{1}$ \\ ${ }^{1}$ Department of Hydraulic Engineering and Geotechnics, University of Agriculture in Cracow \\ ${ }^{2}$ Graduate of University of Agriculture in Cracow
}

\begin{abstract}
Usability of fly ash for filtration barriers. The results of permeability and compressibility tests of the fly ash from Skawina Power Plant were presented in the paper. These tests were carried out in the aspect of its usage in filtration barriers in municipal and industrial waste landfills. It was stated that the tested fly ash can not be used for filtration barriers, mainly because of granulation and filtration criteria. Although, the addition of another soil or a hydraulic binding agent would improve its granulation and would increase impermeability.
\end{abstract}

Key words: fly ash, filtration barrier, coefficient of permeability, compressibility

\section{INTRODUCTION}

Different types of wastes, mainly fly ash, slag, ash-slag mixtures, microspheres and fluidized bed combustion ash, are created as a result of coal combustion in the production of electricity and thermal energy. They are called coal combustion wastes $(\mathrm{CCW})$ and they can be valuable materials with many possible uses and substitutes for natural mineral materials that are used in the construction industry or earthworks. Despite that, reusing of coal waste is insufficient and every year about 34 million tons of waste (CSO 2013) are deposited on Polish landfills, causing degradation of the natural envi- ronment. The storage of coal wastes is the most expensive and the least beneficial way of their disposal.

The amount of produced waste is the reason why new ways of their usage are still searched, one of them is a production of new materials which are based on wastes, thanks to that there are many new possibilities of their usage, for example in landfill barriers (Plewa et al. 2009), landfill rehabilitation (Koda 2012) or - with sewage sludge - to limit erosion of landfill slopes (Koda and Osiński 2011). Landfills are engineering structures, significantly harmful to the natural environment and classified as the third geotechnical category (Rozporządzenie Ministra Transportu... 2012). The purpose of every landfill is to isolate and safely store wastes, which will guarantee limitation of their negative influence on the environment. Therefore every landfill should have a liner, which will ensure its impermeability and protect groundwater from pollution by possible leachate.

Usability evaluation of soils for liners in landfills is based on Environmental Law (2001), Waste Management Act (2013) and Regulation on landfills (2013). The regulation includes criteria for the subsoil which can be a natural 
geological barrier for disposed waste. These criteria concern the extension of the soil layer, its thickness and the permeability coefficient depending on the type of waste disposed on the landfill. Where these requirements are not fulfilled, an artificial liner is designed, which is at least $0.5 \mathrm{~m}$ thick, made from a soil and it fulfils the permeability criterion $k \leq 1 \cdot 10^{-9} \mathrm{~m} \cdot \mathrm{s}^{-1}$. The permeability coefficient value as the basic criterion for soil evaluation is not enough, because in the landfill liner there are other processes, which can dominate over filtration. Therefore it is necessary to determine physical and mechanical properties of the soil before a usability evaluation for mineral liners is carried out (Majer 2007). These rules concern both natural and anthropogenic soils, which can be used for mineral liners (Wysokiński 2007).

Using the fly ash as a material for mineral liners is justified by its physical, chemical and mechanical properties. The fly ash has the ability to absorb and reduce leachate because of a high water absorption (up to $80 \%$ ) and low draining $(2-16 \%)$. These values depend on the thickness and density of the tested layer. Based on tests of Gruchot et al. (2012), it was stated that chemical substances content in water eluate from fly ash and ash-slag mixture do not exceed the allowable concentrations, whereas there are higher concentrations of trace elements and $\mathrm{pH}$ reaction. The shear strength and the load capacity, which was based on the bearing ratio (CBR), are comparable or higher than for mineral soils with similar granulation.

Permeability coefficient of coal wastes from different sources of combustion is low and decreases in time (Sobik-
-Szołtysek et al. 2013). The fly ash built into the hydraulic barriers has the permeability of about $10^{-6}-10^{-9} \mathrm{~m} \cdot \mathrm{s}^{-1}$ and its hydraulic conductivity decreases along with the increase in moisture content during compaction (Zabielska-Adamska 2006a).

The chemical stabilizers have a significant influence on compressibility of the fly ash. Addition of $1-2 \%$ of binding agent can totally reduce swelling, it also causes an increase in the shear strength parameters and in the bearing ratio of the swelling ashes (Zabielska-Adamska 2006b, 2008, Gruchot and Pacławska 2012). When values of the permeability coefficient are too high, the fly ash can be improved by the addition of bentonite or chemical stabilizers. Thanks to them it gains lower hydraulic conductivity without any negative influence on the mechanical properties. Lipiński et al. (2007) showed that a self-hardening cement-bentonite mixture can significantly mitigate hazard of landfill sites.

\section{MATERIAL AND METHODS}

The purpose of this paper was to examine the possibility of using the fly ash from Skawina Power Plant for the mineral filtration barriers in a municipal and industrial landfills or as an additional filling in a natural impermeable layer that has insufficient thickness.

The scope of this paper included determination of the basic geotechnical parameters of the fly ash, i.e. granulation, specific density, compaction parameters, permeability coefficient and compression modulus. The physical parameters of the fly ash were determined using standard methods for the mineral soils. 
The falling-head permeability tests with consolidometer were carried out under the load of $12.5 \mathrm{kPa}$. The specimens were $6.5 \mathrm{~cm}$ in diameter and $2 \mathrm{~cm}$ high, they were compacted at the optimal moisture content and the compaction indexes $\left(I_{s}\right)$ equal to $0.90,0.95$ and 1.00 .

The compressibility of fly ash was determined using oedometer tests, on samples that were $7.5 \mathrm{~cm}$ in diameter and $1.9 \mathrm{~cm}$ high, at compaction indexes $\left(I_{S}\right)$ equal to 0.90 and 1.00. Increments of vertical static load of $12.5,25,50,100$, 200 and $400 \mathrm{kPa}$ were applied to the sample or unload at 24-hour-intervals. The last load level was applied until the full consolidation was reached. The samples were formed directly in the ring of the apparatus, at moisture content close to optimal.

\section{RESULTS AND DISCUSSION}

The silt fraction dominated in the grain-size distribution of the fly ash; there were over $81 \%$ of silt, over $10 \%$ of sand and $8 \%$ of clay (Table 1). According to the geotechnical terminology, fly ash was classified as a silt ( $\mathrm{Si}$ ).

The specific density was $2.2 \mathrm{~g} \cdot \mathrm{cm}^{-3}$ and maximum dry density at the optimal moisture content of $34 \%$ was $1.13 \mathrm{~g} \cdot \mathrm{cm}^{-3}$.

The shear strength parameters were high and they depended on the compaction (Gruchot and Sieczka 2013). The

TABLE 1. Geotechnical characteristics of fly ash

\begin{tabular}{|c|c|c|c|c|}
\hline \multicolumn{2}{|l|}{ Parameter } & Symbol & Unit & Value \\
\hline \multicolumn{5}{|l|}{ Grain-size distribution: } \\
\hline \multicolumn{2}{|l|}{- gravel $(2-63 \mathrm{~mm})$} & $\mathrm{Gr}$ & \multirow{4}{*}{$\%$} & - \\
\hline \multicolumn{2}{|l|}{- sand $(0.063-2 \mathrm{~mm})$} & $\mathrm{Sa}$ & & 10.5 \\
\hline \multicolumn{2}{|l|}{- silt $(0.002-0.063 \mathrm{~mm})$} & $\mathrm{Si}$ & & 81.3 \\
\hline \multicolumn{2}{|l|}{- clay $(<0.002 \mathrm{~mm})$} & $\mathrm{Cl}$ & & 8.2 \\
\hline \multicolumn{4}{|l|}{ Name acc. to PN-EN ISO 14688-2:2006 } & Silt (Si) \\
\hline \multirow{3}{*}{\multicolumn{2}{|c|}{ Grain diameters }} & $\mathrm{d}_{10}$ & \multirow{3}{*}{$\mathrm{mm}$} & 0.002 \\
\hline & & $\mathrm{d}_{30}$ & & 0.008 \\
\hline & & $d_{60}$ & & 0.026 \\
\hline \multicolumn{2}{|l|}{ Uniformity coefficient } & $\mathrm{C}_{\mathrm{U}}$ & - & 10.7 \\
\hline \multicolumn{2}{|l|}{ Coefficient of curvature } & $\mathrm{C}_{\mathrm{C}}$ & - & 1.0 \\
\hline \multicolumn{2}{|l|}{ Specific density } & $\rho_{\mathrm{s}}$ & $\mathrm{g} \cdot \mathrm{cm}^{-3}$ & 2.20 \\
\hline \multicolumn{2}{|l|}{ Maximum dry density } & $\rho_{\mathrm{ds}}$ & $\mathrm{g} \cdot \mathrm{cm}^{-3}$ & 1.13 \\
\hline \multicolumn{2}{|l|}{ Optimal moisture content } & o.M.c. & $\%$ & 34.30 \\
\hline \multirow{2}{*}{$\begin{array}{l}\text { Angle of internal friction* at compaction index } \\
\text { of }\end{array}$} & 0.90 & \multirow{2}{*}{$\varphi$} & \multirow{2}{*}{$\circ$} & 28.50 \\
\hline & 1.00 & & & 33.60 \\
\hline \multirow{2}{*}{ Cohesion* at compaction index of } & 0.90 & \multirow{2}{*}{$c$} & \multirow{2}{*}{$\mathrm{kPa}$} & 42.50 \\
\hline & 1.00 & & & 38.20 \\
\hline
\end{tabular}

*acc. to Gruchot and Sieczka (2013). 
increase of compaction index from 0.90 to 1.00 caused the increase of the angle of internal friction by over $5^{\circ}$ and decrease of cohesion by over $4 \mathrm{kPa}$ (Table 1).

\section{Permeability coefficient}

The permeability tests results (Fig. 1) showed that the highest permeability was at the beginning of the tests and it decreased along with time (Fig. 2). In case of samples at the lowest compaction, stabilization of the flow and permeability coefficient was noticed on the first day of the test, whereas for the highest compaction it was at the end of the tests, on the fifth day.

The average values of the permeability coefficient run from $1.09 \cdot 10^{-7}$ to $2.80 \cdot 10^{-8} \mathrm{~m} \cdot \mathrm{s}^{-1}$ (Table 2). The increase of compaction index from 0.90 to 0.95 caused a decrease of permeability coefficient by one order of magnitude. Further increase of compaction index up to 1.00 did not cause any changes in the permeability coefficient value.

While comparing the obtained values of permeability coefficient to the values for mineral soils it can be stated that fly

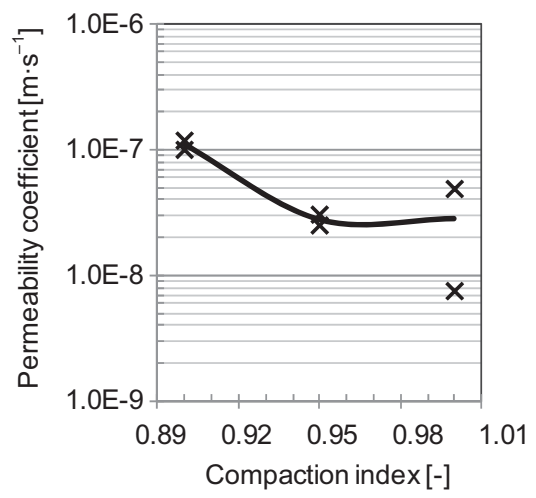

FIGURE 1. Relationship between the permeability coefficient index and the compaction index

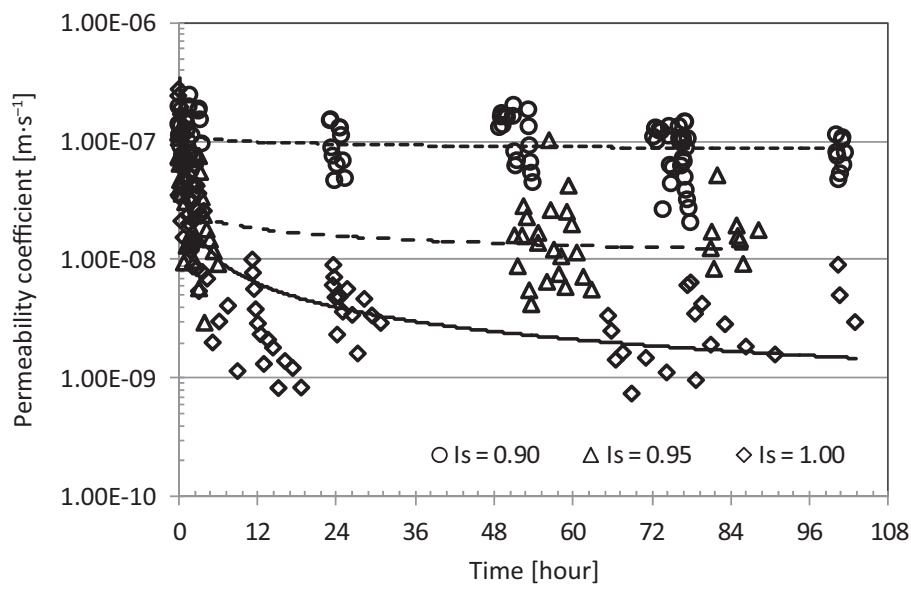

FIGURE 2. Relationship between the permeability coefficient and the duration of the test 
TABLE 2 . Average values of the permeability coefficients $\left(k_{\mathrm{T}}\right.$ and $\left.k_{10}\right)$ of fly ash

\begin{tabular}{|c|c|c|c|}
\hline \multirow{2}{*}{$\begin{array}{c}\text { Compaction index, } \\
I_{S}(-)\end{array}$} & $k_{\mathrm{T}}\left(\mathrm{m} \cdot \mathrm{s}^{-1}\right)$ & \multicolumn{2}{|c|}{$k_{10}\left(\mathrm{~m} \cdot \mathrm{s}^{-1}\right)$} \\
\cline { 2 - 3 } & \multicolumn{2}{|c|}{ sample } & average \\
\hline \multirow{2}{*}{0.90} & $1.05 \cdot 10^{-7}$ & $1.18 \cdot 10^{-7}$ & \multirow{2}{*}{$1.09 \cdot 10^{-7}$} \\
\cline { 2 - 3 } & $8.78 \cdot 10^{-8}$ & $9.98 \cdot 10^{-8}$ & \multirow{2}{*}{$2.77 \cdot 10^{-8}$} \\
\hline \multirow{2}{*}{0.95} & $2.25 \cdot 10^{-8}$ & $2.49 \cdot 10^{-8}$ & \multirow{2}{*}{$2.80 \cdot 10^{-8}$} \\
\cline { 2 - 3 } & $2.58 \cdot 10^{-8}$ & $3.04 \cdot 10^{-8}$ & \\
\cline { 2 - 3 } & $4.41 \cdot 10^{-8}$ & $4.86 \cdot 10^{-8}$ & \\
\hline \multirow{2}{*}{1.00} & $6.70 \cdot 10^{-9}$ & $7.47 \cdot 10^{-9}$ & \\
\hline
\end{tabular}

ash has the hydraulic conductivity of very cohesive soils (Wiłun 2000). The permeability coefficient of the fly ash classified as silt was lower than the corresponding value for mineral soil with similar granulation.

\section{Compressibility}

The total settlement of the fly ash under the load from 0 to $400 \mathrm{kPa}$ was the highest at the primary compression and compaction index $\left(I_{S}=0.90\right)$ and it was on average $0.78 \mathrm{~mm}$, whereas at the compaction index of 1.00 was $0.48 \mathrm{~mm}$ (Fig. 3, Table 3). These values were a few times higher than the ones at the secondary compression where they were 0.21 at the $I_{S}=0.90$ and 0.17 at the $I_{S}=1.00$. Secondary settlement was equal to the total decompression of the fly ash, which was 0.21 and 0.18 adequately at the $I_{S}=0.90$ and the $I_{S}=1.00$.

Obtained values of the settlement of fly ash reflected in the values of compression modulus. In general for full range of load these values depended on the initial compaction, showing upward trend along with its increase (Table 3). Oedometric modulus of primary compression were relatively low - from nearly $10 \mathrm{MPa}$ at the $I_{S}=0.90$ to a little over $16 \mathrm{MPa}$ at the $I_{S}=1.00$ and they were similar to the values given by the Polish Standard PN-B-03020:1981 for cohesive soils in

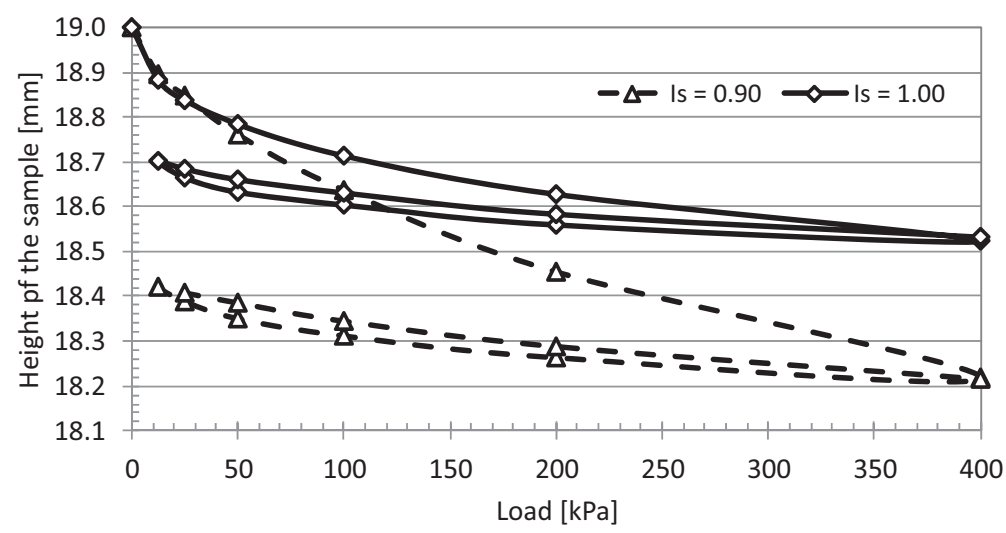

FIGURE 3. Compression curves of fly ash 
TABLE 3. Deformation and oedometric modulus of compression for full range of load ( $0-400 \mathrm{kPa})$

\begin{tabular}{|c|c|c|c|c|c|c|}
\hline \multirow{3}{*}{$\begin{array}{c}\text { Compaction } \\
\text { index (-) }\end{array}$} & \multicolumn{6}{|c|}{ Deformation at (mm) } \\
\hline & \multicolumn{2}{|c|}{ primary compression } & \multicolumn{2}{|c|}{ decompression } & \multicolumn{2}{|c|}{ secondary compression } \\
\hline & sample & average & sample & average & sample & average \\
\hline \multirow{2}{*}{0.90} & 0.82 & \multirow{2}{*}{0.78} & 0.22 & \multirow{2}{*}{0.21} & 0.22 & \multirow{2}{*}{0.21} \\
\hline & 0.74 & & 0.19 & & 0.19 & \\
\hline \multirow{2}{*}{1.00} & 0.51 & \multirow{2}{*}{0.48} & 0.21 & \multirow{2}{*}{0.18} & 0.20 & \multirow{2}{*}{0.17} \\
\hline & 0.44 & & 0.14 & & 0.14 & \\
\hline \multirow{3}{*}{$\begin{array}{l}\text { Compaction } \\
\text { index (-) }\end{array}$} & \multicolumn{6}{|c|}{ Oedometric modulus of (MPa) } \\
\hline & \multicolumn{2}{|c|}{ primary compression } & \multicolumn{2}{|c|}{ decompression } & \multicolumn{2}{|c|}{ secondary compression } \\
\hline & sample & average & sample & average & sample & average \\
\hline \multirow{2}{*}{0.90} & 9.26 & \multirow{2}{*}{9.76} & 1.05 & \multirow{2}{*}{1.13} & 33.26 & \multirow{2}{*}{36.09} \\
\hline & 10.25 & & 1.21 & & 38.92 & \\
\hline \multirow{2}{*}{1.00} & 14.87 & \multirow{2}{*}{16.05} & 1.09 & \multirow{2}{*}{1.36} & 37.90 & \multirow{2}{*}{45.40} \\
\hline & 17.23 & & 1.62 & & 52.90 & \\
\hline
\end{tabular}

plastic state. A similar range of values of this parameter is given by Zabielska-Adamska (2006b). Values of oedometric modulus of secondary compression were 4-times higher than of primary compression and ranged from $36 \mathrm{MPa}$ at the $I_{S}=0.90$ to over $45 \mathrm{MPa}$ at the $I_{S}=1.00$. Whereas moduli of decompression were many times lower in rela- tion to modulus of primary as well as secondary compression and they did not exceed $1 \mathrm{MPa}$.

The increase in primary load from 0 to $400 \mathrm{kPa}$ caused an increase in settlement of the fly ash and thus a quite significant increase of modulus of primary compression: 4-times at the $I_{S}=0.90$ and 8 -times at the $I_{S}=1.00$ (Fig. 4). Whereas
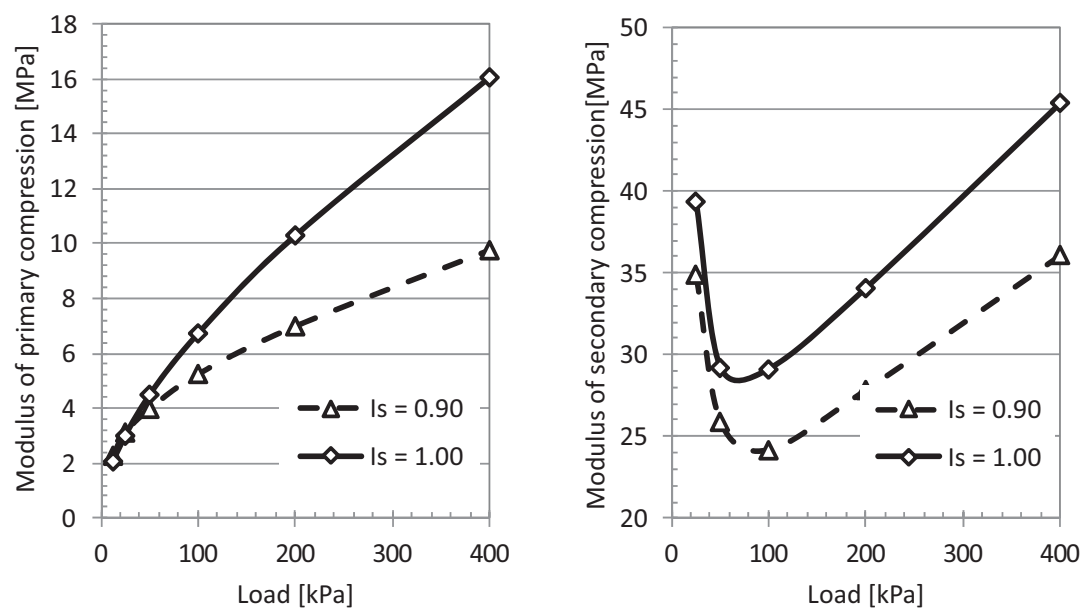

FIGURE 4. Relationship between the load and the average modulus of compression 
at the secondary load in the range of load from 12.5 to $100 \mathrm{kPa}$ decrease in modulus of secondary compression was noticed, but along with further increase in load up to $400 \mathrm{kPa}$ modulus increased. It should be emphasized that modulus of secondary compression were lower at the load of $400 \mathrm{kPa}$ than at the load of $12.5 \mathrm{kPa}$.

Obtained values of compression modulus showed that the tested fly ash has a high compressibility at the primary load, especially at the lower compaction index. At the secondary load compressibility of fly ash was lower and less dependent on the initial compaction, which was caused by a high consolidation during the primary load.

\section{USABILITY EVALUATION OF FLY ASH FOR FILTRATION BARRIERS}

The soils used for liners in a landfill should have a suitable granulation which will allow to obtain proper compaction and required permeability coefficient. A liner should be able to retain its integrity on the onset of non-uniform settlements and it should have a proper strength which will allow to carry normal stress created by the weight of waste. Therefore, the basic usability criterion is the granulation. Wysokiński (1995) states that the clay fraction content should be at least $20 \%$ and the total content of fine fractions, that is silt and clay, should be over $60 \%$. In case of the tested fly ash fine fractions content was close to $90 \%$, so it was higher than the recommended required value (Table 1). However, the clay fraction content was much lower than the required value (only $8 \%$ ), so according to the guidelines of Building Research Institute in Poland (Wysokiński 1995) the granulation criterion was not fulfilled.

The results of compaction tests show that the fly ash has proper values of compaction parameters. The maximum dry density was $1.13 \mathrm{~g} \cdot \mathrm{cm}^{-3}$ and it was higher than the value required by the Polish Standard PN-S-02205:1998 for such types of soils used in earthworks.

The angle of internal friction should be at least $3^{\circ}$ and cohesion $35 \mathrm{kPa}$ for soils used in landfill liners (Wysokiński 2007). Based on research of Gruchot and Sieczka (2013), it can be stated that the shear strength parameters of the fly ash were higher than the required ones (Table 1), therefore the strength criterion is fulfilled.

The minimal value of compression modulus for materials useful in landfill liners is $5 \mathrm{MPa}$ (Wysokiński 2007). Obtained values of modulus of primary compression were over $10 \mathrm{MPa}$ and of secondary compression were $30 \mathrm{MPa}$. Thus, regarding compressibility, tested fly ash fulfills the requirements for mineral filtration barriers.

The basic condition that the material liner must fulfill is the permeability criterion, which is characterized by the value of permeability coefficient. The natural and anthropogenic protective barriers should have this value lower than $1 \cdot 10^{-9} \mathrm{~m} \cdot \mathrm{s}^{-1}$ (Wysokiński 1995, 2007, Rozporządzenie Ministra Środowiska... 2013). Carried out tests showed that the fly ash has the permeability coefficient of $10^{-7}-10^{-8} \mathrm{~m} \cdot \mathrm{s}^{-1}$, so it does not fulfil the permeability criterion. 


\section{CONCLUSIONS}

Based on the carried out test, it can be stated that the fly ash from Skawina Power Plant cannot be used as a material for filtration barriers. Although, it should be emphasized that using waste as a substitute for mineral soils is an important element in the protection of the natural environment because the amount of stored waste decreases. Therefore, using different methods of improving the granulation of fly ash should be considered, for example their granulation and impermeability can be improved by the addition of bentonite or binding agents. However, this issue requires further properly planned research.

\section{REFERENCES}

Central Statistical Office (CSO) 2013: Statistical yearbook of the Republic of Poland. GUS, Warszawa.

GRUCHOT A., PACŁAWSKA J. 2012: Wpływ stabilizacji mieszaniny popiołowo-żużlowej cementem na jej wytrzymałość na ścinanie. [Influence of cement stabilization of the ashslag mixture on its shear strength]. Przegląd Komunikacyjny 9: 32-35 [Engl. summ.].

GRUCHOT A., SIECZKA P. 2013: Wpływ zbrojenia rozproszonego na właściwości geotechniczne popiołu lotnego. [Influence of fibre reinforcement on the goetechnical properties of fly ash]. Drogownictwo 7-8: 241-249 [Engl. summ.]

GRUCHOT A., SZWALEC A., MUNDAŁA P. 2012: Geotechnical and chemical characteristics of ash and slag mixture of Skawina Power Plant (Poland). Geologija 54: 27-34.

LIPIŃSKI M.J., KODA E., WDOWSKA M.K. 2007: Laboratory assessment of permeability of a groundwater protective barrier. Ann. Warsaw Univ. of Life Sci. - SGGW, Land Reclam. 38: 69-79.

KODA E. 2012: Anthropogenic waste products utilization for old landfills rehabilitation. Ann.
Warsaw Univ. of Life Sci. - SGGW, Land Reclam. 44 (1): 75-88.

KODA E., OSIŃSKI P. 2011: Slope erosion control with the use of fly-ash and sewage sludge. Ann. Warsaw Univ. of Life Sci. - SGGW, Land Reclam. 43 (2): 101-111.

MAJER E. 2007: Metodyka doboru gruntu w ramach projektowania mineralnych przesłon izolacyjnych składowisk odpadów. [Methodology of assessment of soil for designing of compacted clay liners (CCLs) in landfills]. Geologos 11: 239-252 [Engl. summ.].

PLEWA F., PIERZYNA P., KANAFEK J. 2009: Ocena porozymetrycznych i filtracyjnych właściwości hydromieszanin popiołu lotnego do budowy barier izolacyjnych podziemnych składowisk. [Assessment of porosimetric and filter properties of fly-ash hydromixtures for construction of isolation barriers in underground waste disposal sites]. Polityka Energetyczna 12: 475-484 [Engl. summ.].

PN-EN ISO 14688-2:2006. Badania geotechniczne. Oznaczanie i klasyfikowanie gruntów. Część 2: Zasady klasyfikacji. [Technical Specification. Geotechnical investigation and testing - Laboratory testing of soil]. Polski Komitet Normalizacyjny, Warszawa [In Polish].

PN-B-03020:1981. Grunty budowlane. Posadowienie bezpośrednie budowli. Obliczenia statyczne i projektowanie. [Construction soils. Spread foundation]. Polski Komitet Normalizacyjny, Warszawa [In Polish].

PN-S-02205:1998. Drogi samochodowe. Roboty ziemne. Wymagania i badania. [Roads. Earthworks. Tests and requirements]. Polski Komitet Normalizacyjny, Warszawa [In Polish].

Prawo ochrony środowiska. [Environmental Law]. Dz.U. $2001 \mathrm{nr}$ 62, poz. 627 [In Polish].

Rozporządzenie Ministra Środowiska z dnia 30 kwietnia 2013 r. w sprawie składowisk odpadów. [Regulation of the Minister of Environment from $30^{\text {th }}$ April 2013 on landfills]. Dz.U. 2013 nr 0, poz. 523 [In Polish].

Rozporządzenie Ministra Transportu, Budownictwa i Gospodarki Morskiej z dnia 25 kwietnia 2012 r. w sprawie ustalania geotechnicznych warunków posadawiania obiektów budowlanych. [Regulation of the Minister of Transport, Construction and Maritime Economy from $25^{\text {th }}$ April 2012 on geotechnical conditions for foundations]. Dz.U. 2012 nr 0, poz. 463 [In Polish]. 
SOBIK-SZOŁTYSEK J., BIEŃ J.B., MILCZAREK M. 2013: Analiza współczynnika filtracji w aspekcie możliwości stosowania alternatywnych materiałów do budowy barier izolacyjnych na składowiska odpadów. Rocznik Ochrona Środowiska 15: 1393-1410 [In Polish].

Ustawa o odpadach. [Waste Management Act]. Dz.U. $2013 \mathrm{nr}$ 0, poz. 21 [In Polish].

WIŁUN Z. 2000: Zarys geotechniki. WKŁ, Warszawa [In Polish].

WYSOKIŃSKI L. 1995: Projektowanie przesłon izolacyjnych na składowiskach odpadów komunalnych. Instrukcja 337. Instytut Techniki Budowlanej, Warszawa [In Polish].

WYSOKIŃSKI L. 2007: Zasady oceny przydatności gruntów spoistych Polski do budowy mineralnych barier izolacyjnych. [Rules of usability evaluation of Polish cohesive soils for mineral liners in landfills]. Instytut Techniki Budowlanej, Warszawa [In Polish].

ZABIELSKA-ADAMSKA K. 2006b: Shear strength parameters of compacted fly ash - HDPE geomembrane interfaces. Geotextiles and Geomembranes 24: 91-102.

ZABIELSKA-ADAMSKA K. 2008: Laboratory compaction of fly ash an fly ash with cement additions. Journal of Hazardous Materials 151: 481-489.

ZABIELSKA-ADAMSKA K. 2006a. Popiół lotny jako materiał do budowy warstw uszczelniających. [Fly ash as a material for building liners]. Rozprawy Naukowe 136. Wydawnictwo Politechniki Białostockiej, Białystok [In Polish].
Streszczenie: Przydatność popiołów lotnych do wykonywania barier przeciwfiltracyjnych. $\mathrm{W}$ pracy przedstawiono wyniki badań współczynników filtracji i ściśliwości popiołów lotnych pochodzących ze zsypów przy elektrofiltrach Elektrowni „Skawina”. Badania były prowadzone w aspekcie oceny możliwości wykorzystania popiołów do budowy barier przeciwfiltracyjnych składowisk komunalnych i przemysłowych odpadów. Stwierdzono, że przedmiotowe popioły lotne nie mogą stanowić materiału do formowania barier przeciwfiltracyjnych, głównie ze względu na kryterium uziarnienia i filtracji. Stosując jednak zabiegi związane $\mathrm{z}$ doziarnieniem popiołów lub stosując spoiwa hydrauliczne, można polepszyć ich uziarnienie i zwiększyć szczelność.

Slowa kluczowe: popiół lotny, bariera przeciwfiltracyjna, współczynnik filtracji, ściśliwość

\section{MS. received in May 2014}

\section{Authors' addresses:}

Andrzej Gruchot, Karolina Koś

Uniwersytet Rolniczy w Krakowie

Katedra Inżynierii Wodnej i Geotechniki ul. Mickiewicza 24-28, 30-059 Kraków, Poland e-mail: rmgrucho@cyf-kr.edu.pl karolinasudyka@wp.pl

\section{Anna Madej}

Kormoranów 9/20, 44-100 Gliwice, Poland e-mail: an_1a@o2.pl 